\title{
Chromosome number and karyotype analysis of wild guava Psidium guineense Sw. - a new report from Tripura, India
}

\author{
Saswati Chakraborti, Sangram Sinha and Rabindra K. Sinha* \\ Department of Botany, Tripura University (A Central University), Suryamaninagar - 799 130, Tripura (W), India \\ *khsinhark@yahoo.co.in
}

\begin{abstract}
The chromosome number and karyotype of Psidium guineense Sw. was investigated. The species had the chromosome count of $n=22$ and $2 n=44$ with a karyotype formula $2 \mathrm{~A}_{s \mathrm{~m}}^{s \mathrm{~s}}+8 \mathrm{~B}_{\mathrm{m}}+24 \mathrm{C}_{\mathrm{rm}}+10 \mathrm{D}_{s \mathrm{~m}}$. The karyotype of the species was slightly asymmetric with a little variation in chromosome length. The species revealed 4 pairs of metacentric, 12 pairs of nearly metacentric and 6 pairs of sub-metacentric chromosomes one of which also had secondary constriction. No meiotic irregularities were recorded. The chromosome constancy of the karyotype recorded in the present study justifies a new record of the present endemic threatened species growing wild in Tripura.
\end{abstract}

Keywords: Psidium guineense Sw. chromosome number, karyotype, endemic, Tripura

\section{Introduction}

Psidium L. of the family Myrtaceae, a tropical American genus with over 100 species and mostly represented by evergreen trees and shrubs with edible berries (Mabberlay, 1990). In India the genus is represented by three introduced species, among them $P$. guineense Swartz. is endemic to Tripura (Deb, 1961; Chakraborti et al., 2005).

Number of potential uses of the species has been reported in the literature (Hedrick, 1972; Tanaka, 1976; Morton, 1987; Verheij and Coronel, 1992; Nazarudeen, 2001). Ethno-medicinally, young leaves and soft twigs of the species are used in the treatment of toothache and gum problem and leaves are used in gastric, cold and bronchitis problems. Locally, fruits are consumed as nonconventional minor fruit and are rich in vitamin $C$ and sugar content (Chakraborti et al., 2007).

Chromosomal studies dealing with somatic chromosome number determination and its ploidy level are of fundamental consideration for any given species in understanding the basic structure of the genetic complement. In literature, there has been no report on somatic chromosome number and karyomorphological details of $P$. guineense $\mathrm{Sw}$. and in particular for this wild guava growing in this Northeastern state Tripura. Although number of cytological works are recorded in common cultivar of Psidium guajava L. (Atchinson, 1947; Sharma \& Majumdar, 1957; D'Cruz and Rao, 1962; Raman et al., 1971; Majumdar \& Mukherjee, 1971, 1972) and other related species (Atchinson, 1947; Costa \& Martins, 2007).

In view of the known ethnobotanical value, a detailed cytological analysis is carried out along with karyomorphological account to understand the basic genetic structure of $P$. guineense Sw.

Materials and Methods

Study of somatic chromosomes

Research article

CIndian Society for Education and Environment (iSee)
Shoot tips of $P$. guineense Sw. were collected from the plants growing in the University experimental garden and from different population sites growing wild in West district of Tripura. Young shoot tips measuring $2-3 \mathrm{~mm}$ were pretreated with saturated para dichlorobenzene (pDB) solution for 4 hours and 45 minutes at $12^{\circ} \mathrm{C}$ and subsequently fixed in 1:3 acetic acid and ethyl alcohol mixture for overnight. The shoot tips were then treated with $45 \%$ acetic acid solution for 15 minutes followed by hydrolysis in $5 \mathrm{~N} \mathrm{HCl}$ at $12^{\circ} \mathrm{C}$ for 1 hour. Finally shoot tips were washed with distilled water for $7-8$ times and treated again with $45 \%$ acetic acid solution for 10 minutes. Shoot tips were stained with $2 \%$ aceto - orcein (N) $\mathrm{HCl}(9: 1)$ mixture for overnight at room temperature. The shoot tips were squashed in $45 \%$ acetic acid solution (Sharma \& Sharma, 1980) for observation. At least 100 metaphase plates were scanned and 5 well spread metaphase cells were randomly selected and drawn for different chromosome measurements with the aid of drawing prism under compound microscope with oil immersion objective $(\times 1268)$. Microphotographs were taken with Nikon FDX - 35 microscope with photographic attachment and was suitably enlarged. In preparing the karyotype, measurements of long arm, short arm, total chromosome length and centromeric index were used. Total Forma percentage (TF\%) of chromosomal complements was also calculated (Levan et al., 1964). Karyogram of the species was constructed from the microphotographs of respective metaphase plates.

Meiotic chromosome study

Young flower buds of $P$. guineense was fixed in 1: 2 glacial acetic acid - ethyl alcohol mixture for 2 hours, then in 1:3 acetic - ethanol mixture for overnight and finally transferred to $70 \%$ ethanol for $3-4$ days. Then the buds were treated with $45 \%$ acetic acid for 10 minutes, followed by warm hydrolysis in $1 \mathrm{~N} \mathrm{HCl}$ for 30 minutes at $55^{\circ} \mathrm{C}$. Finally after thorough washing in distilled water flower buds were stained in $2 \%$ aceto - carmine for 2 - 3
"Wild guava: a new report" http://www.indjst.org
Chakraborti et al. Indian J.Sci.Technol. 
Indian Journal of Science and Technology

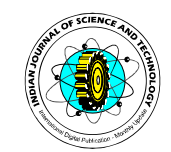

hours and smeared in $45 \%$ acetic acid. As the cytoplasm takes colour, smearing in $45 \%$ acetic acid gives desired result.

$$
2 \mathrm{~A}_{\mathrm{sm}}^{\mathrm{sc}}+8 \mathrm{~B}_{\mathrm{m}}+24 \mathrm{C}_{\mathrm{rm}}+10 \mathrm{D}_{\mathrm{sm}}
$$

. The average size of the

Table 1. Karyotype and measurements of somatic metaphase chromosomes of Psidium guineense Sw.

\begin{tabular}{|c|c|c|c|c|c|c|}
\hline $\begin{array}{c}\text { No. of } \\
\text { chromosome } \\
\text { complements }\end{array}$ & $\begin{array}{l}\text { Length of whole } \\
\text { chromosome } \\
(\mu \mathrm{m}){ }^{*} \text { Mean } \pm \text { SD }\end{array}$ & $\begin{array}{l}\text { Length of short arm } \\
(\mu \mathrm{m}){ }^{*} \text { Mean } \pm \text { SD }\end{array}$ & $\begin{array}{c}F \% \\
* \text { Mean } \pm \text { SD }\end{array}$ & $\begin{array}{c}\text { Nature } \\
\text { of Primary } \\
\text { constriction }\end{array}$ & $\begin{array}{l}\text { Chromosome } \\
\text { Types }\end{array}$ & Remark \\
\hline 2 & $1.80 \pm 0.57$ & $\begin{array}{l}0.55 \pm 0.19 \\
0.39 \pm 0.00\end{array}$ & $\begin{array}{l}30.56 \pm 2.12 \\
19.07 \pm 1.00\end{array}$ & $\begin{array}{l}\mathrm{sm} \\
\mathrm{sm}\end{array}$ & A & $\begin{array}{l}\text { Chromosome } \\
\text { with secondary } \\
\text { constriction }\end{array}$ \\
\hline 4 & $1.46 \pm 0.24$ & $0.73 \pm 0.12$ & $50.00 \pm 0.00$ & $\mathrm{~m}$ & \multirow{3}{*}{ B } & \\
\hline 2 & $1.46 \pm 0.16$ & $0.73 \pm 0.08$ & $50.00 \pm 0.00$ & $\mathrm{~m}$ & & \\
\hline 2 & $1.10 \pm 0.16$ & $0.55 \pm 0.08$ & $50.00 \pm 0.00$ & $\mathrm{~m}$ & & \\
\hline 2 & $1.83 \pm 0.22$ & $0.75 \pm 0.07$ & $40.98 \pm 1.57$ & $\mathrm{~nm}$ & \multirow{12}{*}{ C } & \\
\hline 2 & $1.61 \pm 0.23$ & $0.62 \pm 0.14$ & $38.51 \pm 1.98$ & $\mathrm{~nm}$ & & \\
\hline 2 & $1.58 \pm 0.11$ & $0.66 \pm 0.15$ & $41.77 \pm 2.35$ & $\mathrm{~nm}$ & & \\
\hline 2 & $1.57 \pm 0.02$ & $0.59 \pm 0.01$ & $37.58 \pm 0.17$ & $\mathrm{~nm}$ & & \\
\hline 2 & $1.51 \pm 0.21$ & $0.58 \pm 0.16$ & $38.41 \pm 2.67$ & $\mathrm{~nm}$ & & \\
\hline 2 & $1.50 \pm 0.24$ & $0.64 \pm 0.08$ & $42.67 \pm 2.19$ & $\mathrm{~nm}$ & & \\
\hline 2 & $1.44 \pm 0.19$ & $0.57 \pm 0.09$ & $39.58 \pm 1.71$ & $\mathrm{~nm}$ & & \\
\hline 2 & $1.41 \pm 0.13$ & $0.57 \pm 0.09$ & $40.43 \pm 4.61$ & $\mathrm{~nm}$ & & \\
\hline 2 & $1.39 \pm 0.11$ & $0.57 \pm 0.09$ & $41.07 \pm 4.46$ & $\mathrm{~nm}$ & & \\
\hline 2 & $1.30 \pm 0.15$ & $0.50 \pm 0.09$ & $38.46 \pm 2.87$ & $\mathrm{~nm}$ & & \\
\hline 2 & $1.20 \pm 0.25$ & $0.59 \pm 0.06$ & $49.17 \pm 1.60$ & $\mathrm{~nm}$ & & \\
\hline 2 & $1.19 \pm 0.20$ & $0.46 \pm 0.09$ & $38.66 \pm 2.55$ & $\mathrm{~nm}$ & & \\
\hline 2 & $1.88 \pm 0.46$ & $0.65 \pm 0.21$ & $34.57 \pm 1.94$ & $\mathrm{sm}$ & \multirow{5}{*}{ D } & \\
\hline 2 & $1.74 \pm 0.31$ & $0.61 \pm 0.13$ & $35.06 \pm 2.80$ & $\mathrm{sm}$ & & \\
\hline 2 & $1.48 \pm 0.15$ & $0.46 \pm 0.13$ & $31.08 \pm 2.12$ & $\mathrm{sm}$ & & \\
\hline 2 & $1.42 \pm 0.07$ & $0.53 \pm 0.15$ & $37.32 \pm 1.17$ & $\mathrm{sm}$ & & \\
\hline 2 & $1.25 \pm 0.37$ & $0.32 \pm 0.10$ & $25.60 \pm 2.51$ & sm & & \\
\hline
\end{tabular}

\section{Results}

${ }^{*}$ Mean of 5 measurements. $m=$ median,

The metaphase cells of $P$. guineense Sw. revealed $2 n$ $=44$ somatic chromosomes in all the metaphase cells (Fig. 1) which is a new record of the species. No numerical variation in somatic chromosome number was recorded. The chromosomes were small sized and mostly represented by median types of chromosomes. There were 4 pairs of median $(\mathrm{m}), 12$ pairs of nearly-median $(\mathrm{nm})$ and 6 pairs of sub-median $(\mathrm{sm})$ chromosomes in which one pair had secondary constriction (Fig. 2). On the basis of primary constrictions and size of chromosomal complements the chromosomes were grouped into four morphological types:

Type A Small chromosomes $(1.80 \pm 0.57 \mu \mathrm{m})$ bearing two constrictions, primary and secondary; both were sub-median in position.

Type B Chromosomes were short sized measuring from $1.46 \pm 0.24 \mu \mathrm{m}$ to $1.10 \pm 0.16 \mu \mathrm{m}$ and with median primary constriction.

Type C Shot sized chromosomes with nearly median primary constrictions and were measured from $1.80 \pm$ $0.22 \mu \mathrm{m}$ to $1.19 \pm 0.20 \mu \mathrm{m}$.

Type D Chromosomes with sub - median primary constriction and size range was $1.88 \pm 0.46 \mu \mathrm{m}$ to $1.25 \pm 0.37 \mu \mathrm{m}$.

Minute details of the chromosomal complements was characterized by having karyotype formula

Research article

CIndian Society for Education and Environment (iSee) chromosomal complements was $1.48 \mu \mathrm{m}$ with a size range of $1.10 \mu \mathrm{m}-1.88 \mu \mathrm{m}$ (Table 1) and with a TF value

Fig. 1. Somatic metaphase plate of $P$. guineense $S w$. $(2 n=44)$ [Bar: 4.78um]. 2. Karyogram of the species. 3A. Meiotic metaphase - I of $P$. guineense showing $n=22$ bivalents [Bar: $4.78 \mu \mathrm{m}$ ], $3 B$. Camera lucida drawing of the same [Bar: $7.89 \mu \mathrm{m}]$.
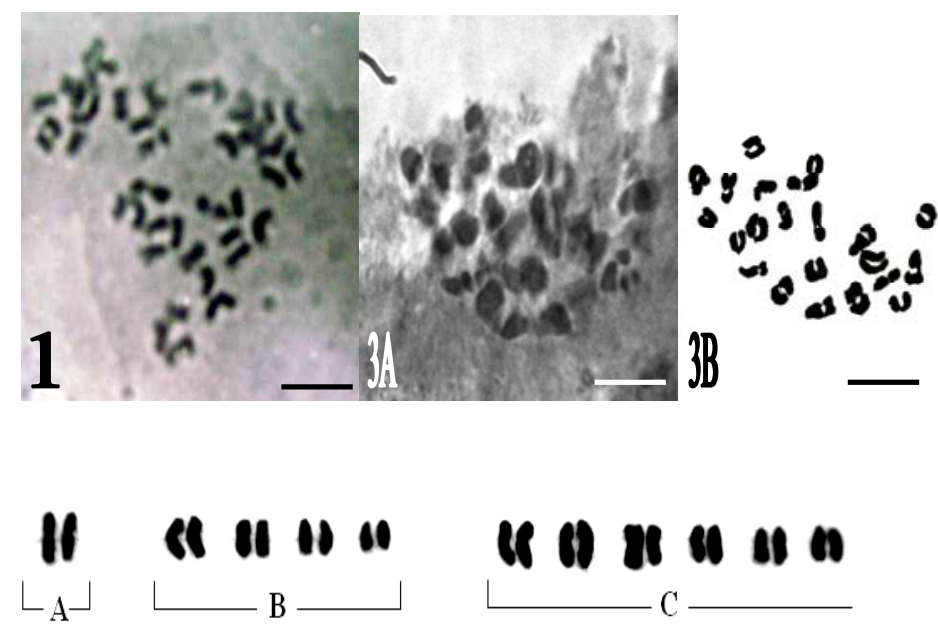

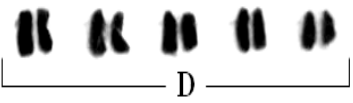

2

"Wild guava: a new report" http://www.indjst.org
Chakraborti et al. Indian J.Sci.Technol. 
$40.07 \%$. Meiotic analysis of pollen mother cells of $P$. guineense revealed 22 normal bivalents (Figs. 3 A - B). No meiotic irregularities like secondary association were recorded in their meiotic cells. Anaphase distribution of bivalent chromosomes was normal.

\section{Discussion}

Analysis of detailed chromosome morphology in $P$. guineense has enabled to disclose a clear picture of a standard karyotype. Previous cytological records on different species of Psidium suggests the existence of ploidy series with a basic chromosome number $\mathrm{x}=11$ (Atchinson, 1947; Costa and Martins, 2007). Variation in ploidy was also reported in many cultivars of $P$. guajava L., (Kumar and Ranade, 1952; Naithani and Srivastava, 1966) in spite of diploid somatic chromosome number $2 \mathrm{n}=2 \mathrm{x}=22$ ( $\mathrm{D}^{\prime}$ Cruz and Rao, 1962; Roy and Jha, 1962b). However, somatic chromosome number recorded in the present species clearly suggests the multiple of basic chromosome number $x=11$ indicating polyploidy in nature. This finding on $P$. guineense could be attributed due to cytological diploidization in course of evolution and behaves like normal diploid species as recorded in many other taxa (Dana and Datta, 1961; Baquar and Akhtar, 1968; Bairiganjan and Patnaik, 1989). Although such type of variation in somatic chromosome number may occur, but only those survives and gives rise to new form which maintain the basic essential characteristics required by the particular group for its survival. Chromosome number and karyotype constancy recorded in the present study justifies a stable genotypic nature of the species.

The size variation of somatic chromosomal complements of $P$. guineense reveals a tendency to asymmetry. According to Stebbins (1971) the karyotype of this species belongs to the category $2 \mathrm{~A}$ and the accumulation of relative size differences between the chromosomes of the complement suggests its karyotype to be considered as slightly asymmetric (Table 2). Moderate degree of symmetry in Psidium and other members of Myrtaceae were also reported by Vijayakumar and Subramanian (1985). Therefore, the chromosome constancy recorded by us clearly reveals a new record of the wild guava $(P$. guineense Sw.) of somatic chromosome number $2 n=44$.

\section{Acknowledgment}

Authors are highly grateful to GBPIHED of IERP, Almora for financial support to carry out the present work. References

1. Atchison E (1947) Chromosome numbers in the Myrtaceae. Am. J. Bot. 34, 159-164.

2. Bairiganjan GC and Patnaik SN (1989) Chromosomal Evolution in Fabaceae. Cytologia. 54, 51-64.

3. Baquar SR and Akhtar S (1968) Cytogenetical studies of the genus Sesbania from West Pakistan. Cytologia 33,

Table 2. Stebbins categorization of the karyotype of $P$. guineense Sw.

\begin{tabular}{|c|c|c|c|c|}
\hline \multirow[b]{2}{*}{$\begin{array}{c}\text { Ratio } \\
\text { largest/smallest }\end{array}$} & \multicolumn{4}{|c|}{$\begin{array}{l}\text { Proportion of the chromosome with arm } \\
\text { ratio }<2: 1\end{array}$} \\
\hline & 0.00 & $0.01-0.50$ & $0.51-0.90$ & 1.00 \\
\hline & $1 \mathrm{~A}$ & $2 \mathrm{~A}$ & $3 A$ & $4 \mathrm{~A}$ \\
\hline$<2: 1$ & & $\begin{array}{l}P . \text { guineense } \\
2 \mathrm{~A}\end{array}$ & & \\
\hline
\end{tabular}

Research article

CIndian Society for Education and Environment (iSee)

"Wild guava: a new report" http://www.indjst.org
427-438.

4. Chakraborti S, Sinha S and Sinha RK (2005) Psidium guineense Swartz. (Myrtaceae) - an endemic threatened species of Tripura, India. J. Phytol. Res. 18 (2) 209-210.

5. Chakraborti S, Sinha S and Sinha RK (2007) Biochemical changes during fruit ripening of Psidium guineense Swartz. (Myrtaceae) - An endemic wild guava of Tripura, India. J. Phytol. Res. 20 (2) 183-187.

6. Costa IR and Forni-Martins ER (2007) Karyotype analysis in South American species of Myrtaceae. Bot. J. Linn. Soc. 155, 571-580.

7. D'Cruz R and Rao GB (1962) Cytogenetic studies in two Guava aneuploids. J. Ind. Bot. Sci. 41, 316-321.

8. Dana SK and Datta RM (1961) Comparative cytological studies of pollen tubes in diploid and tetraploid species of Sesbania. New Phytol. 60, 295-310.

9.Deb DB (1961) New Record of plants for India from Tripura-1. Bul. Bot. Survey India, Botany, 3(I) 87-89.

10. Hedrick UP (1972) Sturtvant's Edible Plants of the World. Dover Publications Inc., NY.

11. Kumar LSS and Ranade S G (1952) Autoploidy in Guava (Psidium guajava Linn.) Curr. Sci. 3, 75-76.

12. Levan AK, Fredga $K$ and Sandberg A (1964) Nomenclature for centromeric position on chromosomes. Hereditas. 52, $201-220$

13. Mabberlay DL (1990) The Plant Book. Cambridge Univ. Press, Cambridge, UK.

14. Majumdar PK and Mukherjee SK (1971) Aneuploidy in guava. II. Nucleus. 14, 119-131.

15. Majumdar PK and Mukherjee SK (1972) Aneuploidy in guava (Psidium guajava L.). I. Mechanism of variation in chromosome number. Cytologia. 37, 541- 548.

16. Morton J (1987) Brazilian Guava. In: fruits of warm climates. Julia F. Morton, Miami, F. L. pp: 365- 367.

17. Naithani SP and Srivastava HC (1966) Autotetraploidy in Psidium guajava Linn. Naturwissenschaften. 53, 205-206.

18. Nazarudeen A (2001) Occurrence of Psidium guineense Sw. (Myrtaceae) - A lesser known edible fruit plant from Peninsular India. Rheedea. 11 (1), 57-59.

19. Raman VS, Sree Rangasamy SR and Manimekhalai G (1971) Triploidy and seedlessness in guava (Psidium guajava L.) Cytologia. 36, 392-399.

20. Roy RP and Jha RP (1962b) Cytological studies in Myrtaceae. Proc. $49^{\text {th }}$ Indian Sci. Cong. Part 3, 336.

21. Sharma AK and Majumdar A (1957) Structure and behaviour of chromosomes in different varieties of Psidium guajava Linn. I. Proc. $44^{\text {th }}$ Indian Sci. Congr. Part 3: 256.

22. Sharma AK and Sharma A (1980) Chromosome technique - Theory and Practice, Third Edition. Butterworths Ltd. London.

23. Stebbins GL (1971) Chromosomal evolution in higher plants. Edward Arnold, London.

24. Tanaka KL (1976) Tanaka's Cyclopaedia of Edible Plants of the World. Keigaku Publishing Co., Tokyo. Japan.

25. Verheij EWM and Coronel RE (Eds.) (1992) Plant Resources of South-East Asia No. 2, Edible fruits and Nuts. Bogor. Indonesia.

26.Vijayakumar $\mathrm{N}$ and Subramanian D (1985) Cytotaxonomical studies in South Indian Myrtaceae. Cytologia. 50, 513-520. 